\title{
Surgical Treatment of Coledochal Cyst Associated with an Aberrant Posterior Hepatic Duct: Report of a Case and Brief Literature Review
}

\author{
Girolamo Geraci Chiara Lo Nigro Antonio Sciuto \\ Enrico Arnone Giuseppe Modica Carmelo Sciumè
}

Section of General and Thoracic Surgery, University Hospital of Palermo, Palermo, Italy

\section{Key Words}

Choledochal cyst · Surgery · Bilio-jejunostomy

\begin{abstract}
Choledochal cysts (CCs) are rare congenital cystic or fusiform dilatations of the biliary tree that can involve the extrahepatic and/or intrahepatic biliary tree. We report a case of huge type I CC associated with an aberrant posterior hepatic duct. A 52-year-old man presented with a 3-week history of upper right abdominal pain and jaundice and serologic sign of obstructive jaundice. Ultrasonography (US), magnetic resonance cholangiopancreatography and endoscopic retrograde cholangiopancreatography were performed with the diagnosis of CC type I according to the classification of Alonso-Lej and Todani-Watanabe. The indication for surgical resection was posed. The cyst was completely resected and the biliary tract was reconstructed with a double hepatico-jejunostomy using the same Roux limb, since during the surgical dissection a before unrecognized anatomical variation of the right biliary tree (aberrant posterior hepatic duct at VI-VII segment) was identified. The diagnosis of CC is often difficult and US and magnetic resonance cholangiopancreatography are necessary to definite biliary dilatation. Endoscopic retrograde cholangiopancreatography should be the most definitive and reliable procedure for the diagnosis and treatment of bilio-pancreatic disorders. Gold standard treatment is surgery (bilio-jejunostomy) and frozen-section histology should be performed to rule out the presence of cancer. In conclusion, surgery is the gold standard for the treatment of CC type I and does not depend on the age of patients, based on a substantial lifetime risk of developing cholangiocarcinoma. Preoperative study is mandatory to assess the biliary tree morphology and to research any anatomical variation.
\end{abstract}




\begin{tabular}{c|l|l|l}
$\begin{array}{c}\text { Case Reports in } \\
\text { Gastroenterology }\end{array}$ & $\begin{array}{l}\text { Case Rep Gastroenterol 2011;5:73-81 } \\
\text { DOI: 10.1159/000321517 }\end{array}$ & $\begin{array}{l}\text { Published online: } \\
\text { January 29, 2011 }\end{array}$ & $\begin{array}{l}\text { O 2011 S. Karger AG, Basel } \\
\text { ISSN 1662-0631 } \\
\text { www.karger.com/crg }\end{array}$ \\
\hline
\end{tabular}

\section{Introduction}

Choledochal cysts (CCs) are uncommon and congenital anomalies of the biliary tree that occur with an incidence of 1:150,000 live births. They are usually diagnosed in infancy or childhood, only $20-30 \%$ are diagnosed in adults [1]. CCs are more prevalent in eastern countries, especially in Japan, and appear as cystic or fusiform dilatation that can involve the extrahepatic or intrahepatic biliary tree, or both. More than $80 \%$ of CCs are type I cysts according to the Todani and Watanabe classification [2]. Their etiology remains unknown. Symptoms are often unspecific and laboratory evaluation may be normal or with no signs of cholestasis. The diagnosis of CC is often difficult and radiological imaging is necessary to identify biliary dilatation [3]. However, abdominal ultrasonography (US), magnetic resonance cholangiopancreatography (MRCP) and endoscopic retrograde cholangiopancreatography (ERCP) are considered the most definitive and reliable procedures for the diagnosis of a variety of biliary and pancreatic disorders, anatomic variations as anomalous pancreatobiliary junction or co-existing biliary anomalies or anatomical variations around the hepatic hilum [4]. Treatment of CCs is surgical and does not depend on the age of patients, because these subjects carry a substantial lifetime risk of developing cholangiocarcinoma. We report a case of huge type I CC associated with an aberrant posterior hepatic duct.

\section{Case Report}

A 52-year-old man presented with a 3-week history of upper right abdominal pain and jaundice. He had undergone appendectomy 25 years before and videolaparoscopic cholecystectomy 5 years before. At admission, the patient was jaundiced and direct bilirubin was $4.0 \mathrm{mg} / \mathrm{dl}$ (normal 0-0.4 mg/dl), AST $402 \mathrm{U} / \mathrm{l}$ (normal $\leq 37 \mathrm{U} / \mathrm{l})$, ALT $1004 \mathrm{U} / \mathrm{l}$ (normal $\leq 31 \mathrm{U} / \mathrm{l}), \gamma \mathrm{GT}$ 1,986 U/l (normal 8-61 U/l), alkaline phosphatases $483 \mathrm{U} / \mathrm{l}$ (normal 40-129 U/1). An US showed a dilated $(2.3 \mathrm{~cm}$ ) and tortuous extrahepatic bile duct, but at computed tomography (CT) the choledochal dilatation appeared to be $5.5 \mathrm{~cm}$ with a long and voluminous cystic stump. MRCP confirmed the presence of fusiform choledochal dilatation $(4.5 \mathrm{~cm})$ without any endoluminal signals alteration and a long common channel.

ERCP with endoscopic sphincterotomy confirmed the presence of cystic dilatation and it was more definitive in displaying ductal anatomy and the existence of an anomalous pancreatobiliary junction with a long common channel (fig. 1), so the patient underwent an exploratory laparotomy with right subcostal incision, and according to the classification of Alonso-Lej modified by Todani, the CC was classified as type I (fig. 2). The first step was to recognize and dissect the cystic stump (fig. 3 ). Then we mobilized and retracted inferiorly the hepatic flexure of the colon to provide exposure of the duodenal sweep. A Kocher maneuver was performed. Dissection on the anterior cyst wall was carried out inferiorly toward the pancreatic head. Superiorly the dissection proceeded until the common bile duct narrowed, at which point the common bile duct was circumferentially mobilized (fig. 4). Before transecting the cyst below the hepatic duct bifurcation, we observed a before unrecognized anatomical variation of the right biliary tree (fig. 5), so we performed an intraoperative cholangiography that confirmed the presence of an aberrant posterior hepatic duct (VI-VII segment) (ig. 6). Then, a total transmural excision of the cyst was performed, just $1 \mathrm{~cm}$ below the confluence of the aberrant hepatic duct into the choledochal duct. Frozen-section histology ruled out the presence of cancer in the margins of the resected cyst. A Roux-en-Y jejunal loop $50 \mathrm{~cm}$ in length was built and a side-to-side hand-sewn enteroenterostomy established bowel continuity. The Roux limb was brought to the right upper quadrant in a retrocolic position through the transverse mesocolon. The limb easily reached the hepatic duct bifurcation without tension. Each hepatic duct (fig. 7) was then separately anastomosed to the jejunal limb over a temporary silicon stent, such as a pediatric feeding tube. The Roux limb was secured to the transverse mesocolon. Figure 8 shows the intraoperative final result. Histological examination of the specimen revealed dysplastic mucosa of the cyst and disease-free margins of the specimen.

The postoperative period was uneventfully and management consisted in transjugular total parenteral nutrition and postoperative pain control with epidural anesthesia. Total parenteral nutrition 


\begin{tabular}{r|l|l|l}
$\begin{array}{r}\text { Case Reports in } \\
\text { Gastruanterology }\end{array}$ & $\begin{array}{l}\text { Case Rep Gastroenterol 2011;5:73-81 } \\
\text { DOI: 10.1159/000321517 }\end{array}$ & $\begin{array}{l}\text { Published online: } \\
\text { January 29, 2011 }\end{array}$ & $\begin{array}{l}\text { O 2011 S. Karger AG, Basel } \\
\text { ISSN 1662-0631 } \\
\text { www.karger.com/crg }\end{array}$ \\
\hline
\end{tabular}

was continued until the patient regained bowel function and a free diet. Inpatient length of stay was 14 days. Follow-up at 7 months was excellent.

\section{Discussion}

The etiology of CCs remains unknown, but they are considered to be congenital $[5,6]$. It is theorized that the presence of an anomalous pancreatobiliary junction with a long common duct ( $>15 \mathrm{~mm}$ in more than $80 \%$ of cases) without obstruction could be considered as the initiating factor, increasing the risk of chronic retrograde passage of pancreatic secretions into the common bile duct, which leads to dilatation at least, as in our case $[3,7]$.

Biliary cystic disease remains rare, with an incidence of $0.1 \%$ even among adults referred for ERCP; up to $60 \%$ of patients are diagnosed during the first decade of life while $20 \%$ go undiagnosed into adulthood. Type I CC is most common, corresponding to more than $75 \%$ of diagnosed cases [8]. Patients with CC have a 20-30-fold higher risk of developing cholangiocarcinoma than the general population. In fact, $10-30 \%$ of adults with bile duct cysts develop cholangiocarcinoma [9] which may arise in the cyst wall itself, in remnant tissue or in undilated parts of the intra- or extrahepatic bile duct [9].

Long-term survival in patients who have developed malignancy is rare, and the prognosis is the same as that for patients in the general population with cholangiocarcinoma.

Cholangiocarcinoma may develop in all kinds of cysts, but type I ( $80 \%$ of all patients with $\mathrm{CC}$ ) and type IV cysts are associated with a higher incidence, even after cyst excision.

Jordan et al. calculated that the development of bile duct carcinoma in residual CC walls was significantly higher (121.5 times) than in the normal population [7]. Nevertheless, complete excision of these lesions is the treatment of choice as soon as possible, preferably before puberty, in order to decrease the chance of developing cancer [9].

The clinical presentation of this disease is not specific: adult subjects are asymptomatic or usually present with vague symptoms, generally in the right upper abdominal quadrant; rarely they present with the triad of right upper quadrant pain, abdominal mass, and jaundice [7]. About 50\% of patients have undergone cholecystectomy or other biliary surgical exploration before diagnosis. Jaundice is a less frequent feature in adults (10-55\%), whereas cholecystitis, cholangitis and pancreatitis tend to occur at a higher rate (20-60\%). A palpable abdominal mass is rarely appreciated in adults. No specific biochemical liver test variables are diagnostic or specific for bile duct cyst, and abnormal laboratory values are more likely to reflect complications of bile duct cyst, such as pancreatitis or cholangitis, than the cysts themselves [9]. Hepatobiliary imaging, often initiated for evaluation of other pathologies, is useful; US remains the screening study of choice for evaluating the biliary tract, but it can sometimes be limited due to overlying gas, especially in patients presenting with acute abdominal pain. In patients with type I cyst, US may show fusiform dilatation of the common bile duct in the absence of obstructing lesion. The anomaly is detected at ERCP in $90-92 \%$ of patients or at MRCP, is not operator-dependent, and the multiplanar acquisition of axial, coronal, and oblique images is useful for comprehensive evaluation of the biliary tract. MRCP is also useful to detect the presence of lithiasis. The diagnostic results of US and MRCP were similar, whereas diagnostic ERCP remains invasive with a morbidity of $7 \%$ and a mortality of $1 \%$ [10]. 


\begin{tabular}{r|l|l|l}
$\begin{array}{r}\text { Case Reports in } \\
\text { Gastruenterology }\end{array}$ & $\begin{array}{l}\text { Case Rep Gastroenterol 2011;5:73-81 } \\
\text { DOI: 10.1159/000321517 }\end{array}$ & $\begin{array}{l}\text { Published online: } \\
\text { January 29, 2011 }\end{array}$ & $\begin{array}{l}\text { O 2011 S. Karger AG, Basel } \\
\text { ISSN 1662-0631 } \\
\text { www.karger.com/crg }\end{array}$ \\
\hline
\end{tabular}

At present, total resection of the cyst followed by Roux-en-Y hepaticojejunostomy is the operation of choice: this procedure decreases the risk of biliary stasis (with subsequent gallstone formation, cholangitis and pancreatitis) [7] and the chances of developing cholangiocarcinoma [11]. On these bases, treatment of CC by complete cyst resection and restoration of biliary drainage by Roux-en-Y end-to-end hepatico-jejunostomy is a concept that has gradually gained acceptance throughout the world. It has been suggested that nearly complete excision rather than total excision of a cyst at the hepatic or duodenal end will have a negligible effect on the frequency of cancer developing later; however, most surgeons in this field recommend complete cyst resection. Pancreaticoduodenectomy should be reserved for patients with an established malignancy. At its proximal extent, the cyst should be transected just below the hepatic bifurcation, with care taken to exclude any strictures or continuing dilatation of the bile duct. Frozen-section histology should be performed to rule out the presence of cancer. In rare circumstances (severe cholangitis, cyst rupture), temporary external drainage before definitive surgery may be preferable and this can be achieved by percutaneous transhepatic drainage or by open T-tube cholecystostomy (not necessary with previous endoscopic sphincterotomy).

Elective cyst excision, which can be performed with low morbidity and a mortality rate approaching zero, should be carried out easily in experienced hands. The removal of a cyst may be technically challenging owing to extensive fibrosis and inflammation from preoperative or cyst-related complications such as pancreatitis or cholangitis [9]. Factors to consider before surgical treatment of patients with biliary cystic disease include age, presenting symptoms, cyst type, associated biliary stones, ductal anomalies (aberrant ducts), previous biliary surgery, intrahepatic strictures, hepatic atrophy or hypertrophy, biliary cirrhosis, portal hypertension and synchronous biliary malignancy [12].

Pancreaticoduodenectomy should be reserved for patients with an established malignancy. There are not previous reports in the literature of the presence of CC and other biliary tree anomalies.

\section{Conclusion}

Surgery is the gold standard for the treatment of CC type I, based on the risk of malignancy. Preoperative study is mandatory to assess the biliary tree morphology and to research any possible anatomical variation, which should be researched also during surgical exploration to prevent surgical disaster. Frozen-section histology should be performed during surgical resection to rule out the presence of cancer. 


\begin{tabular}{l|l|l|l}
$\begin{array}{r}\text { Case Reports in } \\
\text { Gastroenterology }\end{array}$ & $\begin{array}{l}\text { Case Rep Gastroenterol 2011;5:73-81 } \\
\text { DOl: 10.1159/000321517 }\end{array}$ & $\begin{array}{l}\text { Published online: } \\
\text { January 29, 2011 }\end{array}$ & $\begin{array}{l}\text { O 2011 S. Karger AG, Basel } \\
\text { ISSN 1662--0631 } \\
\text { www.karger.com/crg }\end{array}$ \\
\hline
\end{tabular}

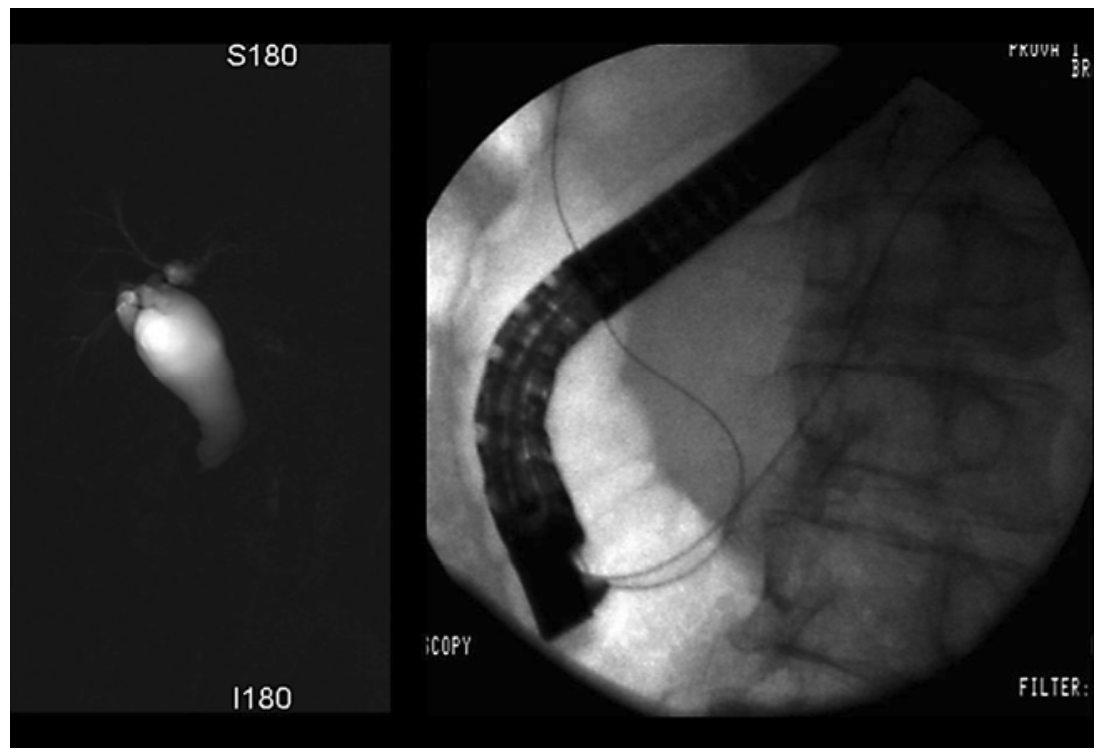

Fig. 1. Imaging at MRCP (left) and ERCP (right).

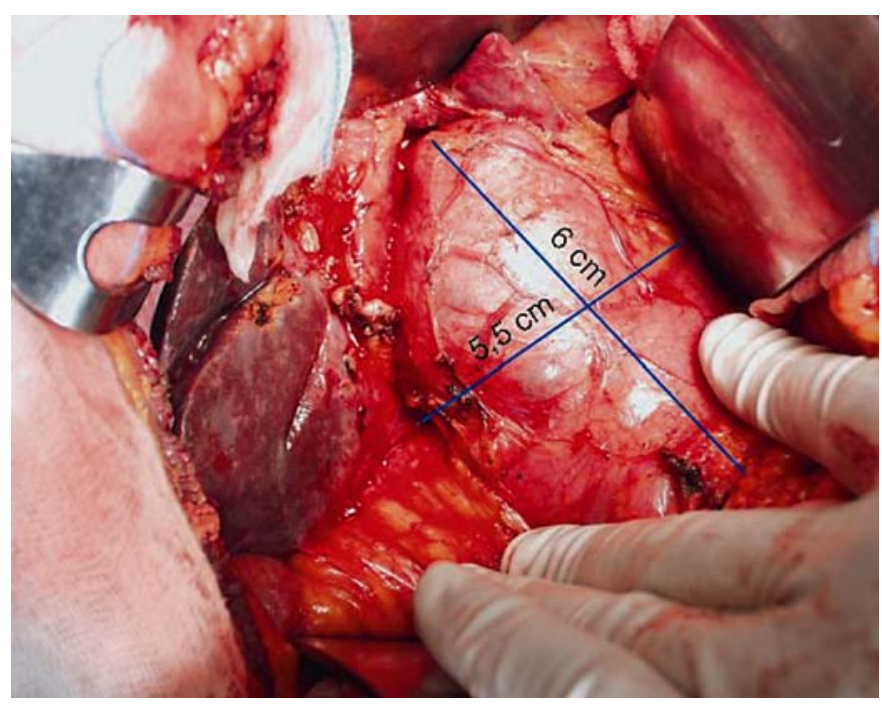

Fig. 2. Intraoperative aspect of the CC. 


\begin{tabular}{l|l|l|l}
$\begin{array}{r}\text { Case Reports in } \\
\text { Gastruenterology }\end{array}$ & $\begin{array}{l}\text { Case Rep Gastroenterol 2011;5:73-81 } \\
\text { DOI: 10.1159/000321517 }\end{array}$ & $\begin{array}{l}\text { Published online: } \\
\text { January 29, 2011 }\end{array}$ & $\begin{array}{l}\text { O 2011 S. Karger AG, Basel } \\
\text { ISSN 1662-0631 } \\
\text { www.karger.com/crg }\end{array}$ \\
\hline
\end{tabular}

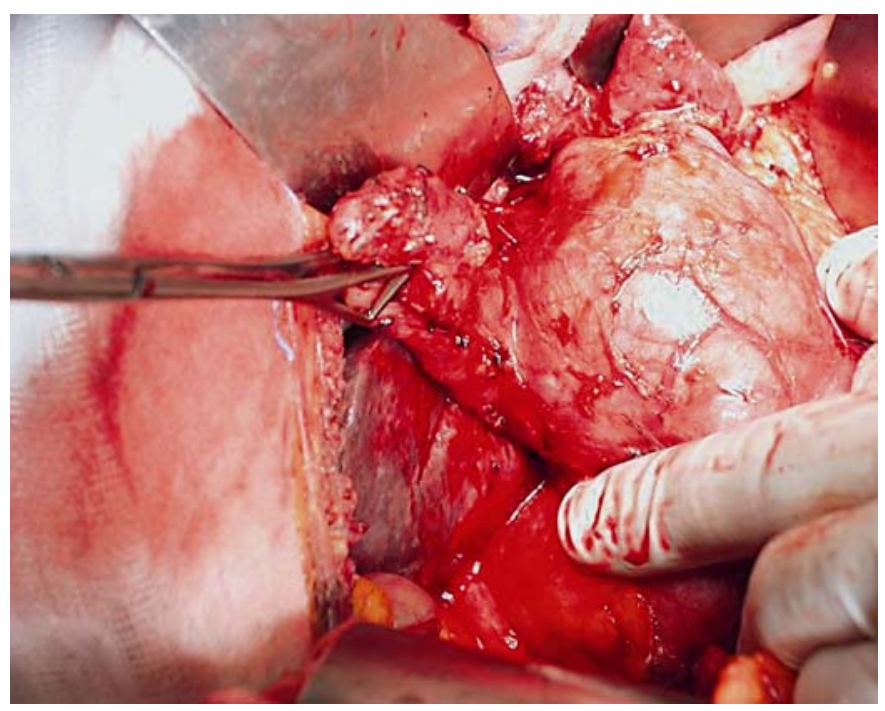

Fig. 3. Dissection of the cystic stump.

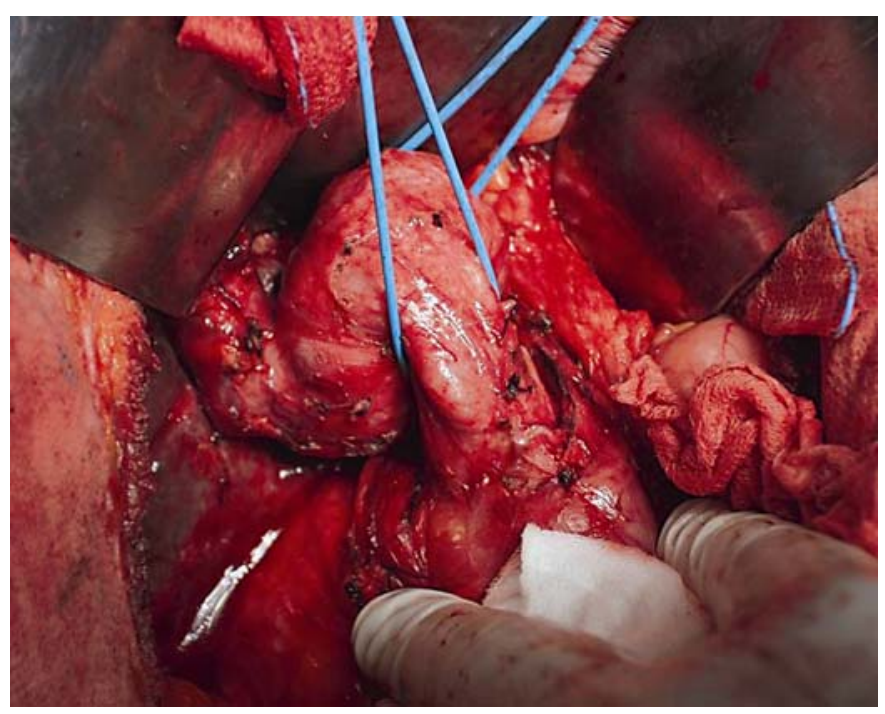

Fig. 4. Common bile duct circumferentially mobilized and isolated. 


\begin{tabular}{l|l|l|l}
$\begin{array}{r}\text { Case Reports in } \\
\text { Gastroenterology }\end{array}$ & $\begin{array}{l}\text { Case Rep Gastroenterol 2011;5:73-81 } \\
\text { DOl: 10.1159/000321517 }\end{array}$ & $\begin{array}{l}\text { Published online: } \\
\text { January 29, 2011 }\end{array}$ & $\begin{array}{l}\text { O 2011 S. Karger AG, Basel } \\
\text { ISSN 1662--0631 } \\
\text { www.karger.com/crg }\end{array}$ \\
\hline
\end{tabular}

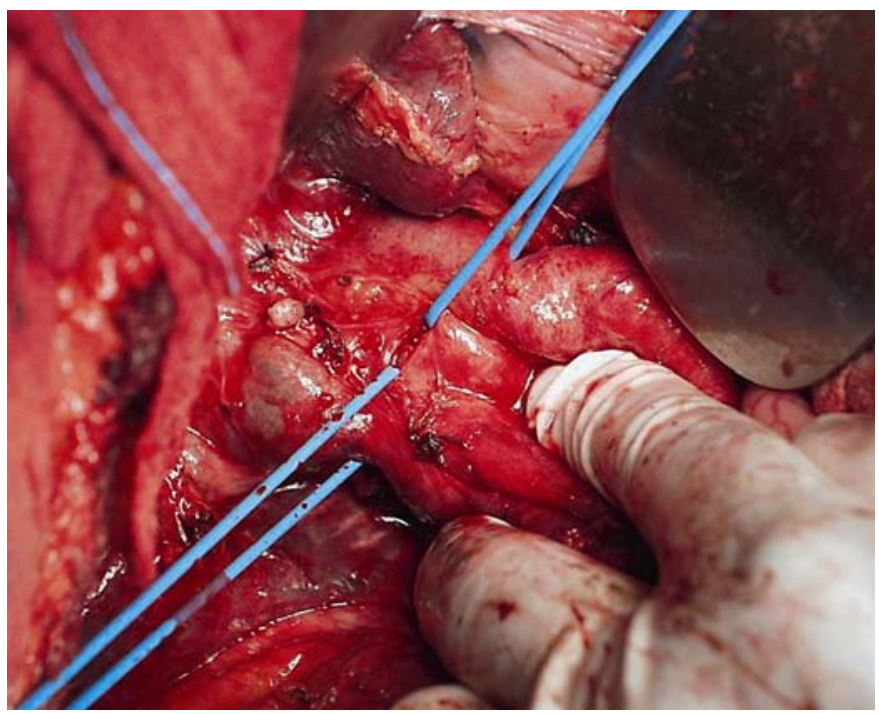

Fig. 5. Presence of before unrecognized anatomical variation of the right biliary tree.

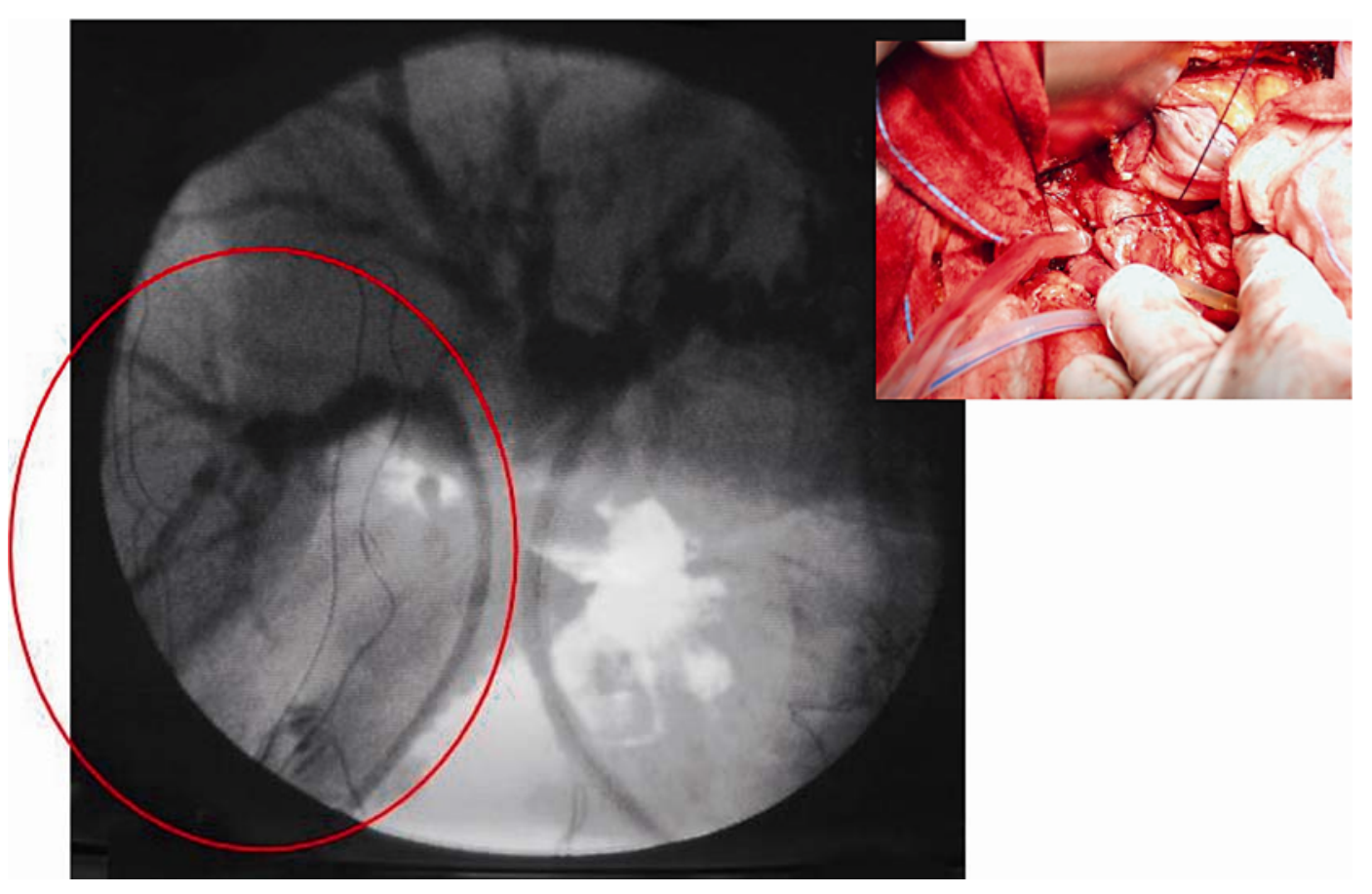

Fig. 6. Intraoperative cholangiography. 


\begin{tabular}{l|l|l|l}
$\begin{array}{r}\text { Case Reports in } \\
\text { Gastruenterology }\end{array}$ & $\begin{array}{l}\text { Case Rep Gastroenterol 2011;5:73-81 } \\
\text { DOI: 10.1159/000321517 }\end{array}$ & $\begin{array}{l}\text { Published online: } \\
\text { January 29, 2011 }\end{array}$ & $\begin{array}{l}\text { O 2011 S. Karger AG, Basel } \\
\text { ISSN 1662-0631 } \\
\text { www.karger.com/crg }\end{array}$ \\
\hline
\end{tabular}

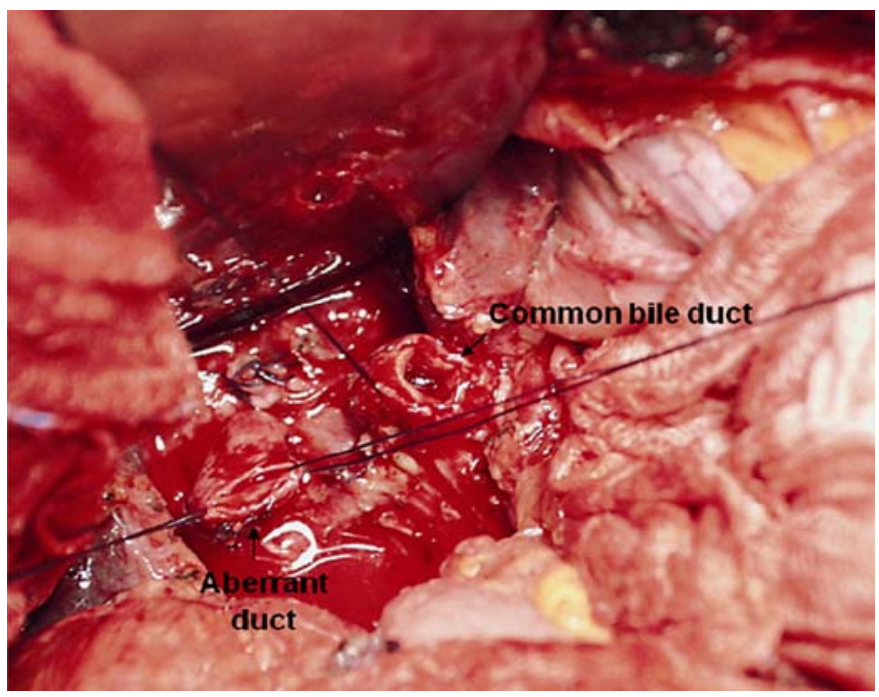

Fig. 7. Each hepatic duct was separately anastomosed to the jejunal limb.

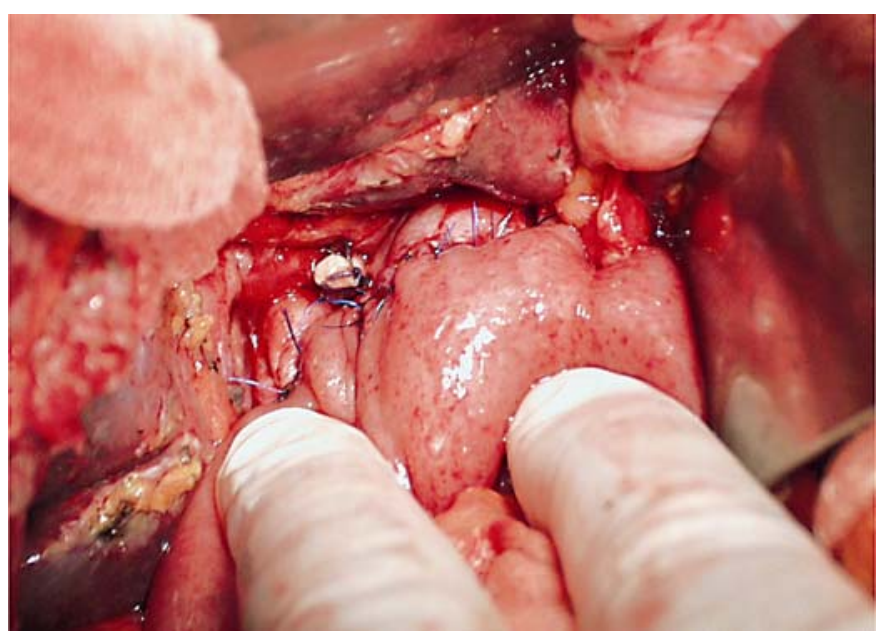

Fig. 8. Intraoperative final result.

\section{References}

$\checkmark 1$ Wiseman K, Buczkowski AK, Chung SW, Francoeur J, Shaeffer D, Scudamore CH: Epidemiology, presentation, diagnosis, and outcomes of choledochal cysts in adults in an urban environment. Am J Surg 2005;189:527-531.

$\checkmark 2$ Todani T, Watanabe Y, Narusue M, Tabuchi K, Okajima K: Congenital bile duct cysts: classification, operative procedures, and review of thirty-seven cases including cancer arising from choledochal cyst. Am J Surg 1977;134:263-269.

-3 Matos C, Nicaise N, Devière J, Cassart M, Metens T, Struyven J, Cremer M: Choledochal cysts: comparison of findings at MR cholangiopancreatography and endoscopic retrograde cholangiopancreatography in eight patients. Radiology 1998;209:443-448.

-4 Todani T, Watanabe Y, Toki A, Ogura K, Wang ZQ: Co-existing biliary anomalies and anatomical variants in choledochal cyst. Br J Surg 1998;85:760-763. 
5 Ishii H, Arai K, Fukshima M: Fusion variation of pancreatic ducts in patient with anomalous arrangement of pancreaticobiliary ductal system. J Hepatobiliary Pancreat Surg 1998;5:227-232.

6 Craig AG, Chen LD, Saccone GT, Chen J, Padbury RT, Toouli J: Sphincter of Oddi dysfunction associated with choledochal cyst. J Gastroenterol Hepatol 2001;16:230-234.

-7 Jordan PH Jr, Goss JA Jr, Rosenberg WR, Woods KL: Some consideration for management of choledochal cysts. Am J Surg 2004;187:790-795.

8 Ammori JB, Mulholland MW: Adult type I choledochal cyst resection. J Gastrointest Surg 2009;13:363-367.

\$9 Söreide K, Körner H, Havnen J, Söreide JA: Bile duct cysts in adults. Br J Surg 2004;91:1538-1548.

10 Frampas E, Moussaly F, Léauté F, Heloury Y, Le Neel JC, Dupas B: MR cholangiopancreatography in choledochal cysts. J Radiol 1999;80:1659-1663.

11 Rush E, Podesta L, Norris M, Lugo D, Makowka L, Hiatt JR: Late surgical complications of choledochal cystoenterostomy. Am Surg 1994;60:620-624.

12 Lipsett PA, Pitt HA: Surgical treatment of choledochal cysts. J Hepatobiliary Pancreat Surg 2003;10:352-359. 